[Radiocarbon, Vol 22, No. 3, 1980, P 718-727]

\title{
AGE STRUCTURE OF HOLOCENE COASTAL SEDIMENTS: GULF OF CARPENTARIA, AUSTRALIA
}

\author{
E G RHODES, H A POLACH, B G THOM, and S R WILSON \\ Research School of Pacific Studies \\ Australian National University, Canberra
}

\begin{abstract}
Shells in beach-ridge and chenier Holocene deposits from the Gulf of Carpentaria, Queensland, have been dated by radiocarbon. Possible contamination of carbonate by post-depositional diagenetic processes, isotopic fractionation, ocean reservoir environmental effect, and association of biological age of sample material with depositional event have been examined in order to validate dating of samples from this environment. A numerical methodology used for comparing 'groups' of ${ }^{14} \mathrm{C}$ dates strongly supports morphostratigraphic evidence that time discontinuities occur within both chenier and beach-ridge sequences. Four episodes are recognized in each area, all younger than ca 5800 years ago, the time when sea level reached its postglacial maximum in the Gulf of Carpentaria. To some extent, these episodes are out of phase, reflecting different modes of strandline accumulation.
\end{abstract}

\section{INTRODUCTION}

The age structure of Holocene coastal sand barriers and chenier plains has been determined in a few localities using the radiocarbon technique. The best known examples are Galveston Island, Texas, western Louisiana, near Scheveningen in the Netherlands, and at Nayarit, on the west coast of Mexico. During the last seven years there has been a concerted effort in eastern Australia to obtain radiocarbon ages from detrital shell samples of prograded sand barriers composed of beach-ridges and chenier deposits (Cook and Polach, 1973; Cook and Mayo, 1977; Thom, Polach, and Bowman, 1978). These ages were used to establish the age sequence of deposition and rates of progradation. E G Rhodes (unpub) working in two areas of the Gulf of Carpentaria, Queensland (fig 1), has obtained dates of 55 shells from both beach-ridge and chenier environments of deposition. This study appears to support the published views of Thom, Cook, and others that there are hiatuses within such depositional sequences.

In order for correlations to be made within and between areas of coastal deposition, it is necessary to establish the validity of ${ }^{14} \mathrm{C}$ results from these environments and a methodology for comparing 'groups' of dates. In this paper we will show how ${ }^{14} \mathrm{C}$ results from both Gulf of Carpentaria sites can be used for these purposes.

\section{Validation of radiocarbon results}

The dating of coastal and near-shore depositional events by radiocarbon age determinations has been accepted as a viable chronologic tool (Olsson, 1959; Olsson and Blake, 1962). In later works, Olsson and Eriksson (1965) discussed contamination by modern carbon and the oceanic reservoir effect. Other authors, such as Mangerud and Gulliksen (1975), Gillespie and Polach (1979) and Rafter and others (1972) dealt with the geographic variations of the oceanic reservoir correction factor. Radiocarbon dating, applied to Holocene coastal sites, is subject to a variety of problems which affect interpretation of the results. Sources of error include contamination at the sample site, isotopic fractionation, and asso- 


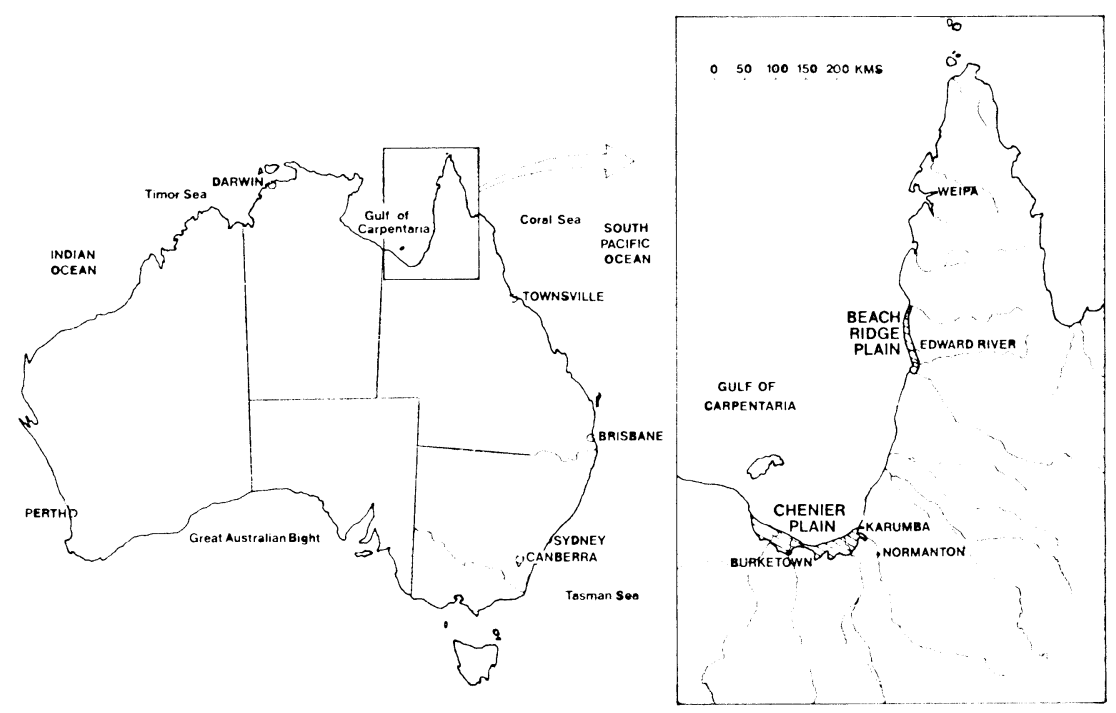

Fig 1. General location of Gulf of Carpentaria, Australia, showing study area of beach-ridge $\left(15^{\circ} \mathrm{S}, 142^{\circ} \mathrm{E}\right)$ and chenier plain $\left(17^{\circ} 30^{\prime} \mathrm{S}, 141^{\circ} \mathrm{E}\right)$. Modern and AD 1903 live shell samples for control come from ca $80 \mathrm{~km}$ north of Weipa.

ciation of sample with event. The reliability of radiometric dates from coastal zones will, therefore, be enhanced if 1$)$ geochemical analyses are undertaken to show little or no contamination of samples, 2) dates from the same or similar stratigraphic units are cross-checked, 3) identification of the geochemical environment is supported by good stratigraphic analysis of the site, and 4) the late Cenozoic tectonic history of the area is understood and the degree of coastal isostatic down-warping associated with marine transgressions is evaluated (Polach and Golson, 1966; Polach, 1976; Thom, 1973).

Ages are reported as ${ }^{14} \mathrm{C}$ years $\mathrm{BP}, i e$, corrected for isotopic fractionation and based on the Libby half-life of 5568 years. The modern reference standard was ANU sucrose, secondary international calibration standard, correlated with 95 percent of ${ }^{14} \mathrm{C}$ activity of NBS oxalic acid, normalized to $\delta^{13} \mathrm{C}=-19 \%$ wrt PDB (Polach, 1979; Currie and Polach, 1980).

For purposes of interpretation, ${ }^{14} \mathrm{C}$ results based on marine shell samples are corrected for oceanic reservoir environmental effect established by Gillespie and Polach (1979) to be $450 \pm 35$ years for the southern and eastern coast of Australia. Corrected results are annotated BP*. To test the applicability of the same correction factor in the anomalously shallow, warm, and well-mixed waters of the Gulf of Carpentaria, two modern samples were dated (ANU-1828 and -2092). The shell fish were collected live in AD 1903 by C Hedley offshore of Mapoon, Queensland, ca $80 \mathrm{~km}$ north of Weipa (fig 1). ${ }^{1}$ ANU-2099 was collected live from $25 \mathrm{~m}$ depth offshore of Edward River in 1978. Determinations on these 'modern control' shells are presented in table 1 .

${ }^{1}$ Australian Museum, Sydney, N S W, specimen no. C14195 and C14280 
TABLE 1

Modern environment ${ }^{14} \mathrm{C}$ concentration shell control samples

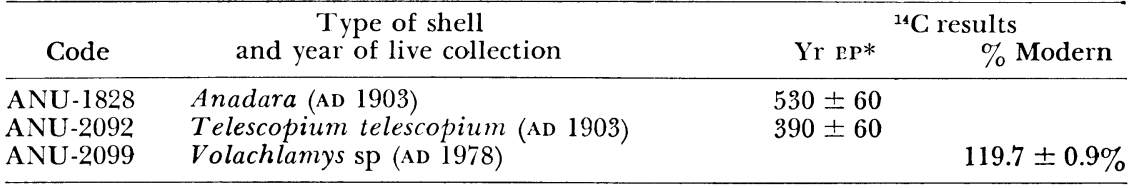

* Corrected for isotopic fraction, and 'age corrected' for difference in time of collection AD 1903 and radiocarbon standard calibration, AD 1950 (Stuiver and Polach, 1977).

The AD 1903 specimens indicate a correction factor of $460 \pm 45$ years (mean of both values). The AD 1978 specimen also agrees with determinations on other 'contemporary' live specimens listed in Gillespie and Polach (1979). Therefore, at this stage, the oceanic correction factor for marine shells collected from the Gulf of Carpentaria will be considered the same as that used for eastern and Southern Australia, $i e$, $450 \pm 35$ years.

Contamination of relict marine shells by carbon of higher ${ }^{14} \mathrm{C}$ activity is a recognized problem (Olsson, Giksu, and Stenberg, 1968). Sub-aerial exposure or contact with freshwater bicarbonate after deposition may induce post-depositional recrystallization and, hence, also affect radiocarbon ages. Chappell and Polach (1972) recognized two modes of recrystallization in corals and Tridacna shells. One of these, the subtle coarsening mode, occurs in a closed system. However, the sparry calcite mode suggests an open system that permits contamination by carbon of different ${ }^{14} \mathrm{C}$ activity. Other authors, including Thom (1973), Bloom and others (1974), and Chappell and others (1974) also refer to the problem of contamination. Despite this, Thom, Polach, and Bowman (1978) emphasize that valid dates from the New South Wales coast can be obtained on shell samples from below the groundwater table because exchange with modern carbon has been minimal. They suggest that $\delta^{13} \mathrm{C}$ and $\delta^{18} \mathrm{O}$ values be measured as they may assist the validation of radiocarbon age determinations.

Vadose recrystallization of biogenic aragonite into sparry calcite proceeds rapidly in the Gulf of Carpentaria. Several age determinations evaluated this effect. First, highly recrystallized shells were divided into an inner and outer fraction (Olsson and Blake, 1962). Second, superimposed samples in relict ridges on the beach-ridge plain provided some notion of the vertical age structure. Comparison of these findings was made with determinations from very young ridges, where recrystallization was minimal. Third, ridges that rested on datable organic peat provided additional data on the relationship of one peat sample and adjacent shell sample. Finally, $\delta^{13} \mathrm{C}$ and $\delta^{18} \mathrm{O}$ ratios were determined on a small group of highly recrystallized samples.

Samp!e ANU-1740 was collected from a pit dug into the most inland Holocene 'perched' chenier ridge on the Karumba transect (fig 1). Test results (ANU-1740A, $5540 \pm 95 \mathrm{BP}^{*}$, the inner fraction of Anadara sp 
shell, 4 percent calcite, 96 percent aragonite and ANU-1740C, $5330 \pm 95$ $\mathrm{BP}^{*}$, the outer fraction, 24 percent calcite, 76 percent aragonite) agree well (Z statistics, Polach, 1972; Ward and Wilson, 1976). Two further samples, ANU-1736 and -1737 were collected by drilling into a relict ridge about $1200 \mathrm{~m}$ from the modern coastline along the Christmas Creek transect placed across a broad beach-ridge plain north of Edward River (fig 1). These ridges are characterized by increased carbonate recrystallization with increasing age. Granular sparry calcite was found $1.5 \mathrm{~m}$ from the surface with sediments grading to comminuted shell fragments below the water table. Low-tide muds occur as a well-defined facies $1 \mathrm{~m}$ thick beneath the beach-ridge sands. ANU-1736, $2680 \pm 75 \mathrm{BP}^{*}$ (shell frag-

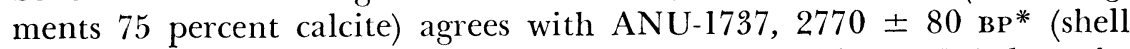
fragments, 4 percent calcite) recovered from low-tide mud below the sand facies. The above results suggest that, in this region, recrystallization is not accompanied by significant change in age.

Vertical age relationship was tested near the Edward River settlement (fig l). ANU-1899, $240 \pm 85$ BP* $^{*}(100$ percent aragonite, Anadara sp) from the ridge crest is compared to the same species found below the ridge base, in intertidal muds, ANU-1898, $160 \pm 80$ BP* (98 percent aragonite). Both have the same age, suggesting that the depositional event involving accumulation of the beach-ridge sand from base to crest is so short that ${ }^{14} \mathrm{C}$ dating cannot resolve any age difference.

The relationship between peat and shell ages was tested in a section of Holocene beach-ridge eroded by the Balaurgah Creek. A silty organic peat (34 percent organic material) about $4 \mathrm{~cm}$ thick underlies calcitecemented marine shells (Anadara and Turritella sp). It contained only mangrove pollen (G Singh, 1976, pers commun) and, thus, was probably subject to tidal inundation during its accumulation. ANU-1739A, 5610 $\pm 95 \mathrm{BP}^{*}$ (Anadara and Turritella sp 95 percent calcite), and the calcite matrix cementing the shells, ANU-1739B, dated $5530 \pm 90$ вр (100 percent calcite), post-date the peat, ANU-1738, $6450 \pm 100 \mathrm{BP}$, in correct stratigraphic sequence.

Although aliquots of most shell samples dated were analyzed by XRD to determine carbonate mineralogy, not all samples could be submitted for determination of $\delta^{13} \mathrm{C}$ and $\delta^{18} \mathrm{O}$ values. ${ }^{2}$ This is regrettable, for Thom, Polach and Bowman (1978) point to the value of $\delta^{13} \mathrm{C}$ and $\delta^{18} \mathrm{O}$ determinations as an additional parameter for assessing the validity of ${ }^{14} \mathrm{C}$ age determinations. Rafter and others (1972) have also recognized that oceanic and freshwater shells can be differentiated by their $\delta^{13} \mathrm{C}$ values, which in the marine environment, have been shown to lie within the range of $0 \pm 2 \%$ wrt PDB. $\delta^{13} \mathrm{C}$ values become negative in a freshwater regime (eg, Thom, Polach and Bowman, 1978; Rafter and others, 1972). Thom, Polach, and Bowman (1978) further suggested that an equilibrated $\delta^{18} \mathrm{O}$ value, for marine shells on the east coast of Australia,

2 No stable carbon and oxygen mass spectrometric facilities existed at ANU in $1976 / 77$, when this study was in progress. Thus, only a few selected determinations could be carried out by $\mathbf{H}$ Polach at the Waikato University, Hamilton, New Zealand, by courtesy of A T Wilson. 


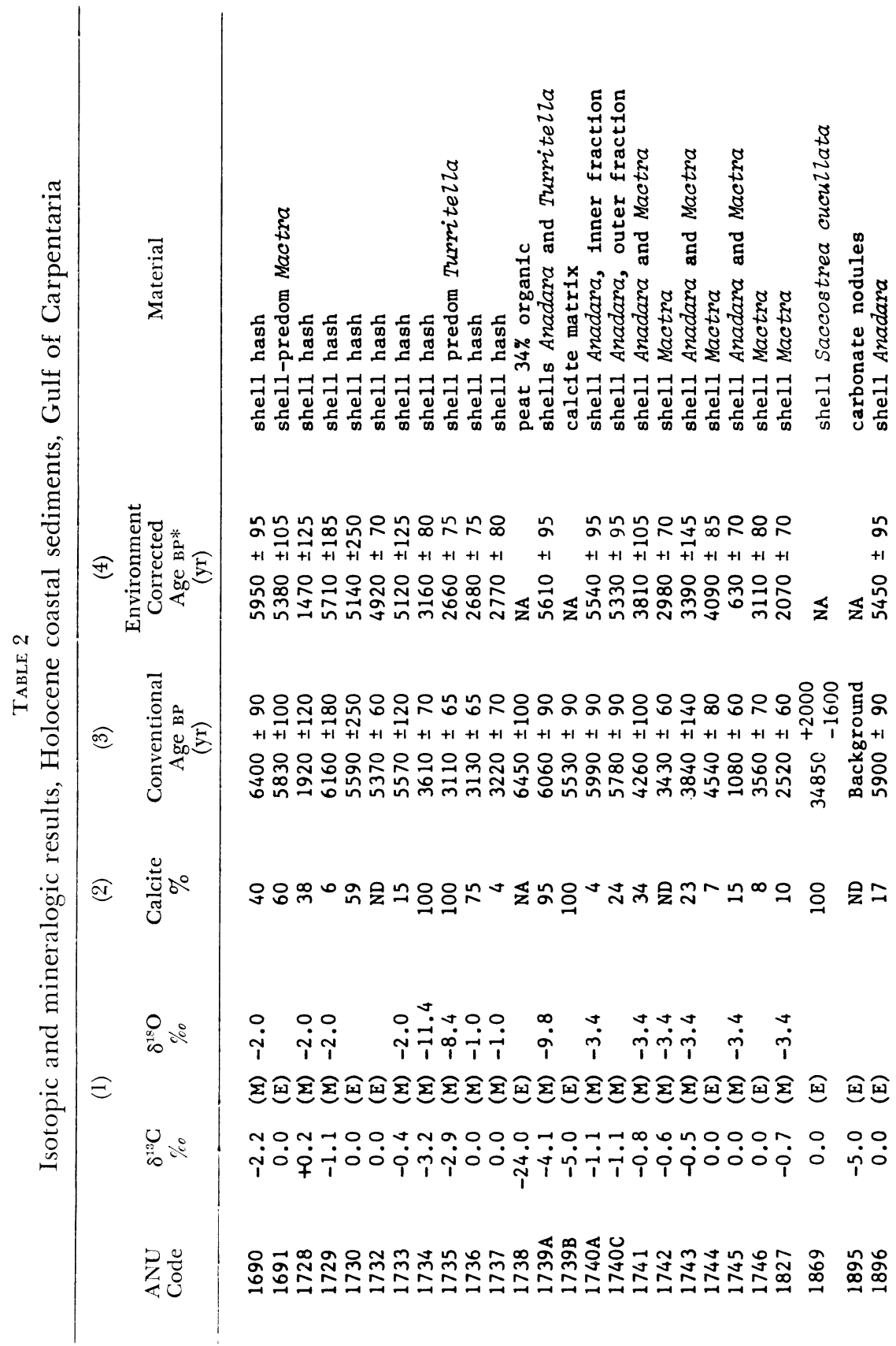




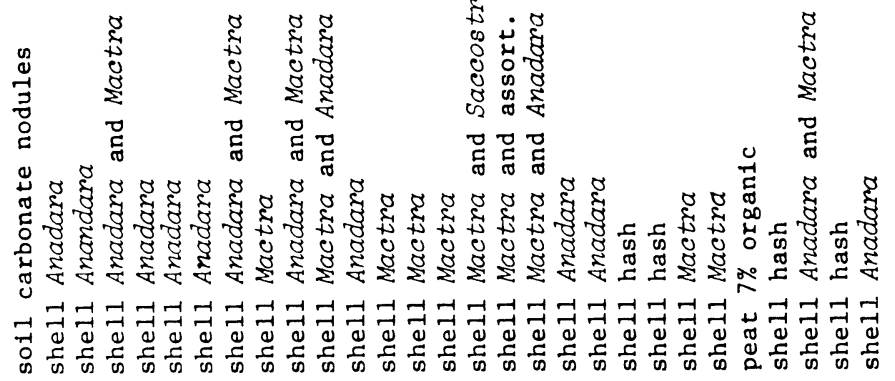

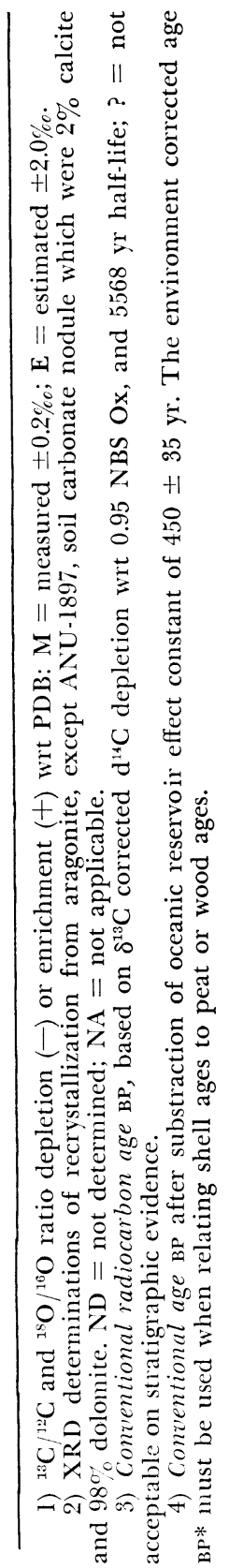


is expected to lie within $-1.9 \pm 1.2 \%$ wrt PDB. Table 2 shows that for samples ANU-1734, $-1739 \mathrm{~A}, \delta^{18} \mathrm{O}$ values range from -8.4 to $-11.4 \%$ accompanied by increased negativity of $\delta^{13} \mathrm{C}(-2.9$ to $-4.1 \%)$. These samples contain $>95$ percent calcite, with Turritella sp identified in 2 of the 3 cases. This either may indicate a change of water regime or simply association with the presence of Turritella sp. These observations do not invalidate the use of ${ }^{14} \mathrm{C}$ results derived from these samples, as the validation study mentioned above failed to reveal 'contamination'. Limited stable isotopic ratio determinations suggest, however, that fluvial (and pluvial) conditions can be recognized and, thus, act as climatic indicators. However, we cannot pursue this point further at this stage.

In summary, shells collected from buried sites, below the upper soil horizon and beneath the 'dry-season' water table, yield acceptable results. Where such precautions were not taken, one result, ANU-2060, $2720 \pm$ $115 \mathrm{BP} *$, did not fit the chronologic sequence. Otherwise, post-depositional recrystallization of aragonite to sparry calcite in the Carpentaria environment was not accompanied by contamination with carbon of different ${ }^{14} \mathrm{C}$ activity. Therefore, all results listed in table 2 (except ANU2060) are assumed to be valid.

\section{Age grouping of radiocarbon results}

In order to present the chronologic sequence of chenier and beachridge deposition in the Carpentaria coastal plain, we must determine if 'cluster' or groups of radiocarbon ages occur that date the same event. When a single event is of shorter duration than can be resolved by radiocarbon dating (see ANU-1898 and -1899), chronologic sequences should be tested by simple approaches, such as Z statistics (Polach, 1972; Ward and Wilson, 1976). However, when depositional events cover a period that can be resolved by radiocarbon dating, Thom, Polach, and Bowman (1978, fig 10) suggest the use of a rank-order display. This graphic 'stairway' permits visual grouping, especially where obvious chronologic gaps exist in the rank-order presentation.

The graphic approach permits effective but subjective grouping and such groupings should be confirmed by numerical analyses to provide statistical evaluation of the confidence level of separation between groups and a group mean and standard deviation based on the assumption that all determinations in the group are such that the sampled age structure for the event has a normal distribution around the mean. Wilson and Ward (in press) suggest analytical techniques for a series of radiocarbon observations that extend the methods for grouping means given by Scott and Knott (1974). The result of such an analysis is a hierarchical arrangement of statistically defined and significant groups, with determinations of group means and their standard deviations.

Groupings of radiocarbon determinations based on a modified Wilson-Ward approach ${ }^{3}$ suggest four distinct episodes of strandline for-

3 The calibration error described by Clark (1975) was omitted because no attempt is being made to correct radiocarbon ages to sidereal years; the variance in sample age due to sunspot activity was also not applied. The 'sampling' variability within each group could change from one group to another. 
mation in the chenier plain (fig 2). Episode I began at or near the time when sea level reached its postglacial maximum ca $5800{ }^{14} \mathrm{C}$ years ago in the Gulf. This brief period of strandline formation continued for approximately 350 years until a hiatus of ca 750 years separated it from episode II. Episode II was a longer event of ca 1600 years' duration, centered ca $3700{ }^{14} \mathrm{C}$ years ago. Episode III is separated from episode II by another hiatus of strandline formation. Episode III was brief (ca 350 years) centered ca $1900{ }^{14} \mathrm{C}$ years ago. Finally, there is evidence of a recent episode IV which may have begun $1200{ }^{14} \mathrm{C}$ years ago and is still active.

The numerical procedure also shows that strandline development on the beach-ridge plain followed an episodic history. Episode I continued for approximately 1200 years after the time of maximum postglacial marine transgression in the Gulf of Carpentaria. No beach-ridges appear in the period 4700 to $3500{ }^{14} \mathrm{C}$ years ago. Episode II of moderate duration (ca 1000 years) produced beach-ridges 3500 to $2500{ }^{14} \mathrm{C}$ years ago. Episode III is centered around $1400{ }^{14} \mathrm{C}$ years ago and present deposition appears to have been active since $400{ }^{14} \mathrm{C}$ years age (episode IV).

\section{CONCLUSION}

Results show that 1) chenier-ridge and beach-ridge deposition occured episodically; 2) ages along a given ridge are consistent; 3) strandline deposition on pre-Holocene landforms ( $c f$ ANU-1895) appears to have begun ca 5500 to $5800{ }^{14} \mathrm{C}$ years ago; 4) progradation was rapid following the transgressive maximum, producing a large number of beach ridges 4500 to $6000{ }^{14} \mathrm{C}$ years ago; 5) anomalous radiocarbon determinations, which would be apparent if adjacent dates contradicted each other, are absent from the chenier plain (the only 'anomalous date' is ANU-2060, from the Edward River transect, which should be older than

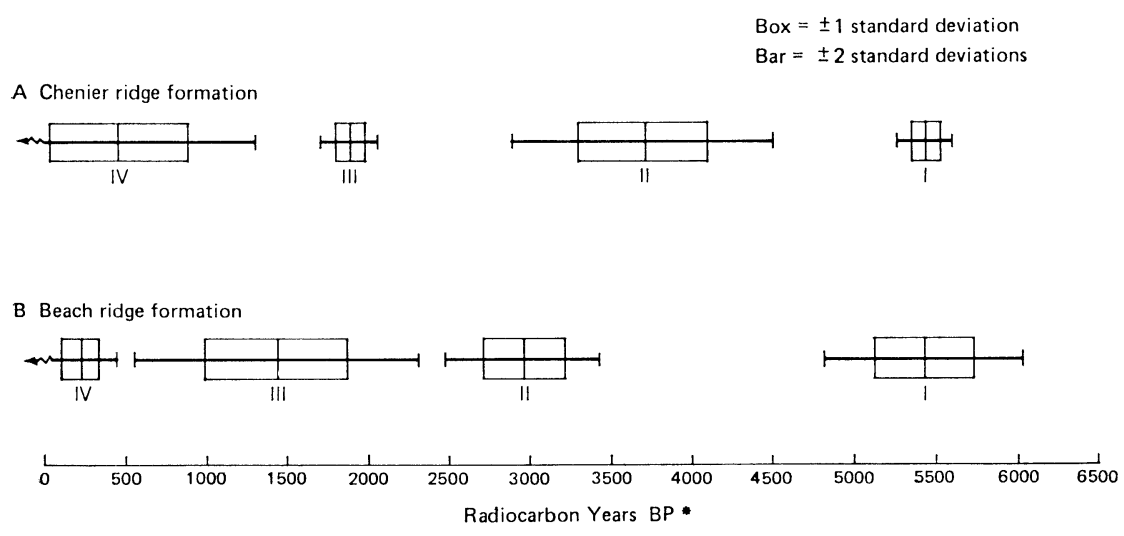

Fig 2. Groupings of radiocarbon age determinations suggest four distinct episodes (Roman numerals) of strandline formation in chenier and beach-ridge plains that may be out of phase at certain times. 
ANU-2059); 6) large numbers of ${ }^{14} \mathrm{C}$ dates obtained from strandline deposits of both chenier and beach-ridge environments can be grouped into events or episodes using numerical procedures developed by Wilson and Ward. This procedure shows that events in the two environments may have been out of phase at certain times during the last 6000 years. Mechanisms responsible for the timing of events are still poorly understood but analysis of the ${ }^{14} \mathrm{C}$ dates certainly draws attention to the need to obtain large numbers of radiocarbon observations before hypotheses can be tested.

\section{ACKNOWLEDGMENTS}

E G Rhodes wishes to thank Donald Walker and Jack Golson, Australian National University, for their support and encouragement. Thanks are also due to the following staff: Lynn Bell, Winifred Mumford, Maureen Powell, Stella Wilkie, Greg Bowman, John Gower, and John Head.

\section{REFERENCES}

Bloom, A L, Broecker, W S, Chappell, J, Matthews, R S, and Mesolella, K J, 1974, Quaternary sea level fluctuations on a tectonic coast: new $T h^{230} / \mathbf{U}^{234}$ dates from the Huon Peninsula New Guinea: Quaternary Research, v 4, p 185-205.

Chappell, John, Broecker, W S, Polach, H A, and Thom, B G, 1974, Problems of dating Upper Pleistocene sea levels from coral reef areas, in Internatl coral reef symposium, 2nd, Proc: Brisbane, v 2, p 563-571.

Chappell, John and Polach, Henry A, 1972, Some effects of partial recrystallization of $\mathrm{C}^{14}$ dating Late Pleistocene corals and molluscs: Quaternary Research, v 2, p 244-252.

Clark, R M, 1975, A calibration curve for radiocarbon dates: Antiquity, v 49, p 251-266.

Cook, P J and Mayo, W, 1977, Sedimentology and Holocene history of a tropical estuary (Broad Sound, Queensland): Australian Dept Natl Development, BMR Bull 170, $206 \mathrm{p}$.

Cook, P J and Polach, H A, 1973, A chenier sequence at Broad Sound, Queensland, and evidence against a Holocene high sea level: Marine Geology, v 14, p 253-268.

Currie, L A and Polach, H A, 1980, Exploratory analysis of the international radiocarbon cross-calibration data: Consensus values and interlaboratory error; Preliminary note, in Stuiver, Minze and Kra, Renee, eds, Internatl radiocarbon conf, 10th, Proc: Radiocarbon, v 22, no. 3, p 933-935.

Gillespie, R and Polach, H A, 1979, The suitability of marine shells for radiocarbon dating of Australian prehistory, in Berger, Rainer and Suess, $\mathbf{H} \mathbf{E}$, eds, Radiocarbon dating, Internatl conf on radiocarbon dating, 9th, Proc: Berkeley/Los Angeles, Univ California Press, p 404-421.

Mangerud, Jan and Gulliksen, Steinar, 1975, Apparent radiocarbon ages of recent marine shells from Norway, Spitsbergen, and Arctic Canada: Quaternary Research, v 5, p 263-273.

Olsson, I U, 1959, Uppsala natural radiocarbon measurements I: Am Jour Sci, Radiocarbon Supp, v 1, p 87-102.

Olsson, I U and Blake, Weston, Jr, 1962, Problems of radiocarbon dating of raised beaches, based on experience in Spitsbergen: Sāertrykk av Norsk Geogr Tidsskr, v 18 , no. $1 / 2$, p $1-18$.

Olsson, I U and Eriksson, Gösta, K, 1965, Remarks on $\mathrm{C}^{14}$ dating of shell material in sea sediments: Prog in Oceanography, v 3, p 253-266.

Olsson, I U, Giksu, Y, and Stenberg, A, 1968, Further investigations of storing and treatment of foraminifera and molluscs for $\mathrm{C}^{\mathrm{t4}}$ dating: Geol Foren $\mathrm{I}$ Stockholm Forh, v 90, p 417-426.

4 Both samples are composed of 100 percent calcite, but ANU-2059 was recovered from a $2.5 \mathrm{~m}$ deep excavation, while ANU-2060 was collected beneath an adjacent swale, which was subsequently found to be subject to freshwater ponding during the wet season. This may be the cause of its contamination by younger carbon. 
Polach, H A, 1972, Cross checking of NBS oxalic acid and secondary laboratory radiocarbon dating standards, in Rafter, $\mathrm{T}$ A and Grant-Taylor, T, eds, Internatl conf on radiocarbon dating, 8th, Proc: Wellington, Royal soc New Zealand, v 2, p 688717 .

1976, Radiocarbon dating as a research tool in archaeology; hopes and limitations, in Barnard, Noel, ed, Symposium on scientific methods of research in the study of ancient Chinese bronzes and southeast Asian metal and other archaeological methods, Proc: Natl Gallery Victoria, Melbourne, p 255-298.

1979 Correlation of ${ }^{14} \mathrm{C}$ activity of NBS oxalic acid with Arizona 1850 wood and ANU sucrose standards, in Berger, Rainer and Suess, H E, eds, Radiocarbon dating, Internatl conf on radiocarbon dating, 9th, Proc: Berkeley/Los Angeles, Univ California Press, p 115-124.

Polach, H A and Golson, J, 1966, Collection of specimens for radiocarbon dating and interpretation of results: Australian Inst Aboriginal Studies, manual no. 2, $42 \mathrm{p}$.

Rafter, T A, Jansen, H S, Lockerbie, L, and Trotter, M M, 1972, New Zealand radiocarbon reference standards, in Rafter, $\mathbf{T} \mathrm{A}$ and Grant-Taylor, $\mathrm{T}$, eds, Internatl conf on radiocarbon dating, 8th, Proc: Wellington, Royal Soc New Zealand, v 2, p 625-675.

Scott, A J and Knott, M, 1974, A cluster analysis method for grouping means in the analysis of variance: Biometrics, v 30, p 507-512.

Stuiver, Minze and Polach, H A, 1977, Discussion: Reporting of ${ }^{14} \mathrm{C}$ data: Radiocarbon, v $19, \mathrm{p} 355-363$.

Thom, B G, 1973, The dilemma of high interstadial sea levels during the last glaciation: Prog in Geography, v 5, p 170-246.

Thom, B G, Polach, H A, and Bowman, G M, 1978, Holocene age structure of coastal sand barriers in New South Wales, Australia: Dept of Geography, Faculty of Military Studies, Univ New South Wales, Duntroon, ACT, Australia, 86 p.

Ward, G K and Wilson, S R, 1976, Procedures for comparing and combining radiocarbon age determinations: a critique: Archacometry, v 20, p 355-363.

Wilson, $\mathbf{S} \mathbf{R}$ and Ward, $\mathbf{G} \mathrm{K}$, in press, Evaluation and clustering of radiocarbon age determinations; procedures and paradigms: Archaeometry, in press. 